\title{
16. Water for country, words for water: Indigenous placenames of north-west Victoria and south-west New South Wales
}

\author{
Edward Ryan \\ La Trobe University
}

In dry land people search for water, in any land people search for meaning in landscapes. This paper continues previous explorations of placenames of Indigenous origin of north-west Victoria and south-west New South Wales begun in 'Blown to Witewitekalk' (Ryan 2002) approaching that region as a geographical, cultural and linguistic entity in order to draw out such meanings. Names for country can be as localised or region wide as the creation figures that placed them on the land and so the question of the existence of placenames for areas of country rather than just specific localities will be considered. Both those 'regional' names and more specific placenames will be examined in the light of their origin as variously; sites of significance in creation stories, reflections of natural features or local flora, and additional types of placename origin. All examples will be considered in the light of the Aboriginal sources where identifiable and the relationships those specific informants had to particular places across the region.

The cultural landscape from which the placenames explored in this paper derive relate to the physical landscape of north-west Victoria and south-west New South Wales. The region in question stretches from the Grampians in the south on northwards past the Murray River to beyond Balranald, and from west of the South Australian border to the central Victorian hills and the Campaspe River. These limits, given the imperfect nature of our knowledge and the ongoing tensions of colonialism, are inevitably both arbitrary and contentious but are based effectively on the extent of the 'limits of affinity' of the Wergaia - the traditional people of my home area. The Wergaia language is a north-western 'western Kulin' language, so named after the common word for man, others of which are Yardwadjali to the south and Wemba Wemba and Perapa Perapa to the north-east and Nari Nari away to the north around Hay. A number of other languages distinct from Kulin such as Yari Yari, Yitha Yitha and Dadi Dadi were also traditionally spoken in the region from around Mildura upriver past Robinvale. The speakers of these languages associated socially and culturally with their neighbours including speakers of a sub-group of north-west Kulin 
languages which display influence from these non-Kulinic tongues. This sub-group included Ladji Ladji, Mathi Mathi, Wathi Wathi, Weki Weki and Boraipur, the language of the Ngarkat away to the west. These particular languages differed from other nearby Kulin languages most obviously in terms of placenames in having the particle ' $i$ ' added to nominative forms familiar from other western Kulin tongues. Hence galk - tree/bone in north-west 'standard' Kulin becomes galki in this group which is described comprehensively in The Mathi Group of Languages (Blake et al. 2011). Similarity of language was not the sole marker of social alliance as can be seen from this mixed picture. In terms of how 'limits of affinity' might be defined the testimony of Captain Harrison who was probably a 'doctor' or 'cleverman' with family links to Morton Plains, Carr's Plains and Swanwater in the southern Mallee and east Wimmera, to the ethnographer A.W. Howitt is of prime importance (Howitt, n.d. - a).

Captain Harrison told Howitt that the Gamutch (Black Cockatoo) and Krokitch (White Cockatoo) moiety divisions extended west a long way towards Wellington and down beyond Mt Gambier where 'another language came in \& people would kill him if he went among them'. He also knew the tribes on the Murray Dadi Dadi, Mathi-Mathi, Wati-Wati up to where about Hay another 'language' came in where the Wiradjuri were. Included within the bounds of the area to the west, Captain mentions, is country of the Buandik people who spoke a nonKulin language. Beyond them though, 'down beyond Mt. Gambier', lay country where a different moiety system pertained. But amongst the people of the Murray, Captain mentions that another moiety system also prevailed as those people were divided between Kilpara and Mukwara - Crow and Eaglehawk. Again there is a mix of language families in this area to the north though he mentions only the area beyond Hay where the Wiradjuri were as where a new 'language' began. The peoples he lists, however, even those to the immediate south of the Wiradjuri, did not intermarry with them and limited their overall contacts with them in order to avoid conflict. The bounds of Wergaia social relations were thus shaped by both affinity of language and social order, as well as their limits.

While the situation in which placenames developed was clearly complex, the question arises of where scholars find them in a part of Australia in which the traditional languages have not been spoken for many years. Sources are varied and include the written accounts of explorers and pastoralists, missionaries, ethnographers and surveyors. The great bulk of placenames examined in this study stem from the maps those surveyors created, a source which provides important spatial as well as linguistic information. ${ }^{1}$ The greatest level of cultural context and detail comes, as might be expected, from the random accounts

1 The majority of cartographic material consulted is found in the Victorian Public Record Series (VPRS) 15899 or VPRS 5920. 
taken from Aboriginal people themselves and recorded by the small group of Europeans interested enough to do so, such as R.H. Mathews and A.W. Howitt in the late 19th and early 20th centuries and Luise Hercus in the 1960s. The region has a dryland ecology, as does much of Australia away from the coastal fringe, and a common concern of both Aboriginal and European people is and has been, access to water. Accordingly this survey begins by looking at placenames referring to water.

Dialectal variants on a common word for water occur in many of the languages of the region - gadjin/gaden/gadini/gayini - and as will be seen it does feature in placenames. Catiabrim (water + spring) is located at Mt Elgin in the northern Wimmera, Moochargatchin (to pick up + water) to the east on the Yarriambiack Creek, Wa-wa-catchi (to follow + water) further east again while Porp-a-gatyein (head + water), Becatyin (mud + water) and Tulgamuruy catyin ('water of the visitors') are found in the southern Wimmera. The nominal forms appear to be straightforward in derivation and certainly the descriptive notation 'chalky or lime water' next to Becatyin on the source map does neatly accord with the literal meaning of muddy water. These nominal forms could however also stem from the travels across the land of creation figures and the verbally based forms listed here certainly would. Tulgamuruy Catyin is found in Smyth (1878 Vol. 2: 178) where it is accompanied by a gloss which illustrates both the benefit and the difficulty of working with such sources; benefit in that gadjin the relevant word for water is featured but difficulty remains in the absence of a reference to visitors. The initial part of the placename however is clearly based on telgug the word for good and certainly in the context of the gloss good water would be sought for visitors, though again the visitors in question would be creation figures. What we might call 'good water' placenames are also found in the form of Towalky alias Tualka Creek in Weki Weki country near Boundary Bend on the Murray and Curndualk again on the Murray upstream from Swan Hill.

A further number of water related placenames is found across the region featuring brim, the word for spring. Brim is found at two locations in the Wimmera and Brimin at two in the Mallee. More complex forms are found such as Bim Bim a Nouchie (springs + mythological figure) at Lake Tyrell and Coonubrin (excrement + spring) at Lake Timboram to its east. The water at Coonubrin was salty which may indicate the name was descriptive of spoilt water. Similarly Gretchie Brem in the northern Mallee was glossed as bitter or salty spring in a list of words taken from Sam Kinnear at the site of the old Ebenezer Mission in the 1930s (Massola n.d.). Sam was born at the mission while his father came from Lalbert and his mother was a Wemba Wemba woman from Long Lake and his use of an initial consonant cluster when writing this placename confirms his family's linguistic origins in the eastern part of Wergaia country. The Gretchie Brem spring features as a camp in a narrative featuring the Bram Brothers, the 
main creation figures for the region, where the brothers battled Djine-djinedj the tawny frogmouth, which reinforces the different levels of association and meaning embodied in placenames (Mathews n.d.).

There are many other water sources that are descriptive in a different sense, utilising shape or size as a basis for a placename. Included in this group we find the word bili for belly, as in the following instances: Muckbilly (alongside + belly) known from two locations on the Wimmera River and Yarriambiack Creek and the remarkable Billyjumbuck (belly + sheep) featuring the pidgin word for sheep. This may indicate the development of a very new yet traditional placename or perhaps that the word which became attached to sheep had other associations previously. There is another word often found as a placename element associated with water; spelt variously Jackel or Jackle. It is found in the name of an early pastoral run, Jackel ba Jackel, along the outlet creek to the north of Lake Albacutya. It is also found as the original name for Lake Lonsdale in the southern Wimmera and referring to a swamp on the Mt Elgin run in the form Torongyjackle where the first part of the name can be read as tjurung = long (Smyth 1878 Vol. 2: 206). Given the spatial context of these placenames it could be assumed that Jackel was a nominal form similar to bili (belly) relating to an enclosed area of water or an alternative nominal form based on the word dja (ground). When we return to the Bram Brothers narratives though we find that Kangaroo formed the Wimmera River, including the outlet channel from Lake Albacutya, and grazed (my emphasis) about Lake Albacutya. It can then be seen that the verb djaga = to eat forms the base of all three placenames with Jackel ba Jackel being read as djagila djagila - 'to go on eating greedily' and Torongyjackle meaning a long area of grazing at that location. In traditional times all these waterways and the edges of lakes and swamps would have been regularly burnt to form new grass and attract kangaroos and other herbivores and so placenames can illustrate the links between cultural and environmental cycles. This is further emphasised by the sourcing of much Bram Brothers narrative from Henry and Teddy Fenton of the Dyakkal Balluk division of the Wergaia, based at Lake Albacutya (Mathews n.d.).

Difficulties of interpretation also present themselves when we look at the placenames Chuangpille from Wonwondah Station in the southern Wimmera and Churingabull well to the northward on Morton Plains, as they could be read as tjuwerung + bili (long + belly) or tjuwerung + pil (long + 'having'). The second form where - pil is a variant of the more common grammatical morpheme -wil for 'having' thus reads as 'the long one' - a nickname for the emu used by Wemba Wemba speakers. It is difficult to judge which is the correct etymology here as while we do not have tokens of Yardwadjali and Wergaia speakers using anything other than the standard form gauir for emu, that does not mean the alternate form was not employed. Certainly emus feature elsewhere in the region 
in placenames through their formal name as discussed below. Stepping away from water sources we have a clear instance of the belly word in the placename for the Victoria Ranges section of the Grampians where the traditional name is Billyweane (belly + fire). This may originate from a story connected with the creation of the range through volcanic activity as there are similar stories connected with the volcanic plains of south-west Victoria as well as an account from Mt Talbot to the west of the Grampians of conflict between Eagle and Cockatoo who alone held fire, where cockatoo was struck on the head letting out fire which 'raged across the land' (Officer, C. n.d.).

An entry from Sam Kinnear's wordlist further illustrates the complexity of naming practices, as bechurnnma winyap is glossed as mountain duck fire. Certainly bidjengal and wanjab are the local words respectively for mountain duck and fire but without a detailed contextual narrative it is impossible to conceive what a mountain duck fire might represent. Other fire-centred placenames are at least partly readable with the Kinnear wordlist and Luise Hercus' (1986: 212) informants providing walbana ngadje - 'they are burning the little fellow', with the little fellow being a widely found mythological figure. That placename refers to a location on the Wimmera River as does Walpana Muya from cartographical sources where the first part of the name again clearly represents 'they are burning' whilst the second could be manja which translates as 'hand' or munja which translates as 'yam'. A yam being burnt might well be a more everyday occurrence but a burnt hand might more readily fit a relevant creation narrative - without which we can draw no further conclusion. It is unclear if 'the Walpa country' to the north of Murrayville held that name before a parish of that name was formed in the early 20th century but it would at least be an apt placename for much of the year. Another form based on walpa in Walpeup certainly existed as a placename attached to a plain prior to the creation of parishes, though at a slightly different location to the current town between Murrayville and Ouyen.

Ngadje, the 'little fellow' who was burnt on the Wimmera River, was as noted a widely cited form of mythological creature who attacked people at night. This creature appears in many placenames beyond the burning place on the Wimmera and his springs at Lake Tyrell such as Dowar Natchie in the Wimmera where he is clearly struck (from dauwa - 'to strike'), Natimuk (ngadje + alongside), and the opaque forms Naghywerrie, Grambonatchie and Nutte Carenn from across the region. He also features in the stand-alone placename of Natya near Tooleybuc and was said in the colonial period to inhabit particular waterholes. Other figures with such associations include Witjewitj who was linked with a well in the desert between the well-known Devon Downs rock shelter and Loxton in the South Australian riverland. Robert Tarby Mason recorded for Norman Tindale how Witjewitj was greatly feared for killing people and Mason's people 
would never linger at the well because of it (Tindale n.d.). Devon Downs itself was named traditionally Naud Naud after another figure well known across the Mallee and Wimmera. The presence in the landscape of these figures or 'powered men' as Tarby Mason called them confirms the cultural and linguistic continuity between that country of the Ngarkat and adjacent Kulin speaking areas of Victoria and New South Wales. It can also be seen how the association of feared figures with these dryland water sources would preserve them from over exploitation and limit the potential for inter-tribal contact and conflict as 'outside' travellers did not pause for long at them on their journeys. While the well known 'bunyip' (banib) was linked with particular waterholes across the region in a cautionary fashion, other such associations showed the limits of affinity mentioned above: as Captain Harrison's countryman Morton Plains Bobby when quizzed by A.W. Howitt dismissed the Wiradjuri creation figure Biami as a dweller in a waterhole on the Wimmera River (Howitt, n.d. - b).

Anything connected with these 'powered men' left an imprint on the landscape that is readable through placenames. Across the region there are axes, clubs and bags, both water and carry bags, left embedded in place. And there are placenames composed of isolated verbal forms that make no sense whatever on their own - but form part of larger narratives when read in conjunction with other names across country. Near the Wimmera River in the placenames Jolem and Jollymuck (waterbag + alongside) - we find waterbags (djul) much where they might expect to be found. Mulkra (malgar) a waddy shield is found on the Murray River in the Riverine language area though the name is widespread to the south and Batchicar (badjiga) an axe found on the Yarriambiack Creek. More intriguingly in the early 1860s the pastoralist Suetonius Officer recorded in his diary how he rode across the plains from his head station at Murray Downs on the Murray River near Swan Hill to 'Tumble Down Waddy' - a name which appears to be English rather than a bowdlerised Aboriginal Word (Officer, S. n.d.). Given that in the colonial period someone who was said by Aboriginal people to have 'tumbled down' had died or indeed been killed, this may represent an event beyond a waddy falling. While it is not possible to determine the precise location of Tumble Down Waddy it was in the same general area as Cunnienyook Station. This placename is clearly based on the word gani for waddy and can clearly be read as gani-nyuk - 'his waddy' and so through examining placenames in two languages it can be established that some form of violent event occurred in the area in the ancestral time.

Similar events are inscribed on the landscape elsewhere. Towan lies to the south of the Murray between Swan Hill and Lake Tyrell, surviving as a locality name and it is also the original name of Long Lake, the home place of Sam Kinnear's mother Sarah Smith, near Lake Boga. It presents an unusual difficulty in that there are two equally valid readings as Towan could stem from duwang (pigmy 
possum) or alternatively dauwan ('they strike'). In a placename list from Swan Hill in Brough Smyth though we find 'Towan' glossed as 'being speared' and dauwa has a more particular meaning of being struck with a weapon or wounded. It is thus much more likely that Towan represents 'they spear', particularly given that there is a placename a little to the south in Towaninny, which translates as 'they strike the neck', as well as the example from the Sam Kinnear list mentioned above of Dowar Natchie which is glossed as 'chop 'is neck', with 'him' being the mythological figure ngadye recorded in other placenames as discussed above. Importantly the narrative of the Bram Brothers conflict with Djire-djiredj the Willie Wagtail links the Brothers with their cousin the turtle and Lake Lalbert, which was originally set in a great plain on which Towaninny was located. Spears were not used in that struggle but the narrative links to the area show it to have been an area where ancestral beings were joined in combat.

Beyond the known 'powered men' and their actions and belongings reviewed above a range of everyday creatures feature in the placenames of the region, in particular birds. This is unsurprising as birds take a central position in the moiety systems and narrative traditions of the region to such an extent that while traditionally Aboriginal people greeted strangers with njanja yauir (what meat) in order to establish how to relate to each other, in later times in English they would discuss what 'their birds' were - even though the system encompassed more than just bird figures. Jenep (djinab) the Sulphur Crested Cockatoo exists as a placename near the Yarriambiack Creek and 'larnee jinnep' - his landing place or more literally his camp lies further west. There is also Perrit Perrit (beredj beredj) in the west Wimmera and a number of instances of Coonawar (gunuwar) the swan across the region. Wahpool Ngurrum Tyrill just to the east of Lake Tyrell probably reflects star lore as such material from that area refers to a male and female crow and the first part of the name Wahpool (wabul) refers to two crows while Tyrill (direl) means sky. Frustratingly the middle word is untranslatable but this may be rectified when Aboriginal astronomy of the region is considered in an informed and rigorous manner. We also find the white cockatoo or corella at Kathica (gadjegar) on the Richardson River near Donald and his foot far to the west at Mt Elgin in the form Tenunggatiga (djine + gadjegar). While these may have been the locations of increase sites they would all have formed part of broader ancestral narratives which are now lost.

Fortunately some lore does survive in regard to the emu (gauir). While Wemba Wemba people favoured a nickname for the emu there is at least one instance of the proper name from their country in the early pastoral station name Giaour, located to the north of the Murray. There are also two extant pastoral maps from widely spaced parts of the region which record in English 'kangaroo and emu plains' and while no explanation of what that might mean is given, it is clearly a carryover from the Aboriginal cultural landscape. The main surviving 
narrative we have featuring emus relates again to the Bram Brothers with the most detailed version taken down by R.H. Mathews from residents of Ebenezer Mission north of Dimboola in the 1890s with the relevant section beginning in the northern Mallee at Wombegrak or Cow Plains Station - now the village of Cowangie (Mathews n.d.). Crow was chased from there by a fearsome giant emu whose name was rendered as Ngindyal by R.H. Mathews and Tchingal by A.W. Howitt. Crow was pursued south to the Grampians where he went through a tunnel and the giant emu in pursuit split the mountain, forming Rose's Gap or Barregowa (path $+\mathrm{emu}$ ), the path of the emu which was named from the event.

Between these two locations, part of the Ebenezer Mission Station was formed from Bonegar Station which could possibly be read as dust of the emu. When petitioning the government for more land for the Mission in the 1860s and 1870s the residents led by Philip Pepper and Jackson Stewart mentioned Bonegar as a place where they and their ancestors 'always liked to go', so it was certainly a place of importance to them (VPRS 44). Lake Hindmarsh was also of importance to them and there we find that Rocky Point was originally known as Garndagauer (Smyth 1878 Vol. 2: 176) which could possibly read as 'nose of the emu'.

While these places fall within the range of the giant emu's tracks their meaning is not readily verifiable as they are not mentioned in the narrative remnants which survive and they exist in only one or two examples. Nevertheless discussion of their meaning is rendered possible when a cultural context exists for the placenames themselves, a context which illustrates that while these animals may take everyday form, they are as likely to be 'powered' as are the other figures.

There is another range of placenames in those that do not feature animals in any form but are based on plants. These names are often relatively simple and direct in form and in addition to further cultural information can provide an insight into the historical ecology of this much changed region. Widji, the word for basket grass occurs widely as in Witchice in the Wimmera, Wichi-pel (basket grass + 'having') at Antwerp on the lower Wimmera River, Witchi at Polkemmet Station in the southern Wimmera and the well-known Wycheproof (basket grass + head) referring to a basket grass hill. Other general references to forms of grasses and groundcovers are also widespread. Jarrok (reeds) appears as a placename on the Lalbert Creek and lower Avoca River in the southern Mallee as well as near Mt Talbot in the southern Wimmera. There are also compound forms featuring reeds such as Tallijark (tongue + reeds) on the Murray and Buckanyany-jowk for Duck Lake in the Wimmera - glossed as 'reedy neck - descriptive of the shape of this lake' in Smyth (1878 Vol. 2: 178). Certainly the second morpheme refers to the neck and the final one to reeds so even without the meaning of the first morpheme it appears this placename gloss has some validity. 
On the Murray we find Booyup (pigface), in the sand-hill country of the western Mallee is Patchywallock (grass + porcupine grass) and Karrun (lignum) in the east Wimmera. Moving to bushes we find Jope (djub) in the south-west Wimmera as well as the important camping spot of Djub Djub Galk near Charlton, and Cutya (bitter quandong) on the outfall of the Yarriambiack Creek. Banksia occurs in placenames in the south and east Wimmera at Warrock Plains, Woorack, and Wurruck Wurruck. Golden wattle occurs at a number of locations across the region, reflecting its physical spread. Galk the generic name for tree also features in a range of locations such as Witchagulk (little + tree) on Morton Plains, Bairbargulk and Gartanagalk in the Wimmera though both of these are only partly readable. Galk also features in Calcalcebeal (tree + tree + redgum) which related to a redgum forest near Mt Talbot. The Redgum occurs in many placenames such as Bael on Morton Plains, Nurrabial down in the Wimmera, and Goorucbeale (sand + redgum). Lake Bael-Bael refers to numbers of trees while Baelapungit (redgum + wire rush) also gives a detailed description of a place on the Murray.

Finally there is a reference to the yellow gum in Papp Plains in the east Wimmera and Bapcha (yellow gum + ground) at two locations elsewhere in the Wimmera, as well as Gourteebap glossed as 'clump of white or yellow gums' in Sam Kinnear's wordlist. The morpheme gurt occurs in many other placenames across the region but lacks contextual material to clarify its meaning, although the final morpheme in Gourteebap is clearly bep (yellow gum). Most of these plant related names take a simple form and could be read as simply descriptive of the region's ecology. Others such as Witchagulk (small + tree) on Morton Plains feature in Bram Brothers narratives and as lore from Mt Talbot states that 'trees formerly had the power of locomotion', plants are as likely as animals to be 'powered' in cultural landscapes and the placenames that illustrate them (Officer, C. n.d.).

It is unsurprising that placenames featuring plants appear at a range of locations across a region regardless of background narratives given the comparable physical spread of the plants. Placenames themselves can recur at widely spaced intervals across a region and illustrate a range of factors impacting on language spread. Witchagulk on Morton Plains is replicated as Witewitekalk further west which reflects the localisation of regional creation narratives. Boomboon in the Yardwadjali area of the Wimmera and Poonboon north of Swan Hill in Wadi Wadi country illustrate the amount of commonality amongst Kulin type languages as well as a linguistic puzzle as the northern example of this probable nominal form does not feature the '-i' ending expected in the Mathi sub-group. Instances of Mournpul at the lakes in Ladji Ladji country and in the country between the Richardson River and Yarriambiack Creek in Wergaia country follow this pattern. Instances occur where the Mathi sub-group '-i' ending does 
appear though and clarifies language boundaries. Waitchie (golden wattle) west of Swan Hill as distinct from Wergaia wadj shows the reach of Wati Wati, as Lepi (manna) to the west of Piangil as opposed to Wergaia lerab shows the extent of Wati Wati or Weki Weki. Further pairs are found with Wennca located near Pine Plains in Wergaia country and Wennga further north in Yu Yu territory, which as a Riverine language is linguistically distinct. In this case as there is not a great overall distance between the locations concerned the adjacent but unrelated languages may have influenced each other. Derrick also occurs in Yu Yu country and is apparently matched by Terrick Terrick in Barapa Barapa country hundreds of miles away to the east. It is possible that djarug (yam) is intended here given that it was a staple traditional food commonly found on the Terrick Plains but analysis is greatly restricted by the limited extent of $\mathrm{Yu} \mathrm{Yu}$ vocabulary surviving. The country of Riverine languages can be identified in part by the presence of monosyllable placenames such as Pom on the Murray as they do not appear in Kulinic languages. At the other extreme we have instances of placenames comprised of phrases such as Mebimdonudgawanginaroong and Murmenon Yannane Merong from near Lake Tyrell, the latter of which probably features the verb 'to walk', yanga. A number of other phrase or sentence length placenames survive from the lower Murrumbidgee River though equally as opaque as these examples. Placenames thus provide clues into questions of historical linguistics as well as historical ecology but most of which must remain unanswered due to paucity of material.

The range of types of placenames explored above demonstrate how the land is culturally encoded in a variety of ways. Names for place as a concept in itself and for terms encompassing discrete areas such as clan or language areas remain to be explored. 'Country' is generally glossed in wordlists from across the region as dja, as are 'ground' and 'earth'. There are no tokens of dja extant though as a placename in its own right in the way for instance that bial and buyub exist as stand-alone names that may refer to single examples of a redgum tree or pigface. $D j a$ is found however as a morpheme in more complex placenames such as Tiega in the central Mallee which could mean 'hopping mouse ground' and Panitya near Murrayville and Tya-moonya near Lake Albacutya which clearly mean 'small ground' and 'yam ground' respectively. Sam Kinnear's aunt Mrs Esther McGuinness contributed 'jabomungul' as a word for 'country' to a vocabulary (Mathew n.d.) and while it is not fully readable it is likely to describe the quality of a particular place as does Tiega, Panitya and Tya-moonya, rather than representing a broader area or 'country' in a general sense.

There are two remaining placenames that do refer to identifiable larger areas of country: Wityelibar glossed in Smyth as 'Avon River and country' and Wandyin Marungu glossed in the same source as 'Morton Plains country' (Smyth 1878 Vol. 2: 176). 'Avon River and country' certainly defines a specific area and could 
reflect the clan estate of a number of clan groups or the geographical location of the river and surrounds. Whilst the name itself is difficult to read there is a Wemba Wemba form for creek withe birr (small + creek/pathway) which may be relevant given the Wergaia/Yardwajali cognate of withe could readily be written as Witye. As this is only a partial translation and there is little in the way of cultural records from the area it is not possible to analyse this placename further. Wandyin Marungu on the other hand presents greater opportunity. While the first word is unreadable the second is clearly marung for Murray Pine and early maps of the area showed pines were plentiful. An animate or 'powered' view of the landscape also features pines as a giant pine tree grew in ancestral times on the shore of Lake Buloke at the south of 'Morton Plains country' which the ancestors of the local people used to climb to the sky-land to hunt there. One day when the people had poor hunting they ate one of dogs of the creation figure Djiwan ${ }^{2}$ (the grey shrike-thrush) who in retaliation placed live coals at the root of the tree which caused it to fall (Howitt n.d. - a). When it fell, members of the local group were left behind in the sky and the pine kernels formed 'a paved road' across Morton Plains to Lake Tyrell, an area that matches the eastern Wudjabalug dialect of Wergaia. Part way across the plain to the north from Lake Buloke lies Tchumm Lake, referred to in pastoral papers from 1850 as 'Chian waterhole'. Clearly this is a rendering of and reference to Djiwan. From that smaller lake, Tatchera Creek takes water in flood years northward again to where it joins up with the Tyrell Creek and eventually reaches Lake Tyrell. Tatchera is derived from djadjera from 'fork of a tree' and so that watercourse may represent a branch of the pine tree as it fell. Certainly the narrative runs across the land in the same way that this and other water courses do with those 'words for water' and other animate landscape features shaped and named by 'powered' men and women still existing as placenames today to those who wish to read the land. The Tatchera Creek lies a short distance to the west of my homeplace and Djiwan in physical manifestation often hops a short way ahead of me as I move across the land. With such persistence and the use of a combination of cultural, historical and environmental sources and forms of knowledge it is clearly possible to take the placenames left to us and again illuminate the land.

\section{References}

Blake, B.J., L.A. Hercus, S. Morey, and E. Ryan 2011, The Mathi Group of Languages, Pacific Linguistics, Canberra.

Hercus, L.A. 1986, Victorian Languages: A Late Survey, Pacific Linguistics, Canberra.

2 This figure is written in A.W. Howitt's manuscripts 'Xurn' and was erroneously written as 'Kurn' in Ryan (2002). 
Indigenous and Minority Placenames

Howitt, A.W. n.d.(a), MS 1053, State Library of Victoria, Melbourne

— n.d.(b), MS 759, Museum Victoria, Melbourne.

Massola, A. n.d., The Aldo Massola Collection: historical photographs principally from Victoria, Al BW, Australian Institute of Aboriginal and Torres Strait Islander Studies, Canberra.

Mathew, J. n.d., MS 950, Australian Institute of Aboriginal and Torres Strait Islander Studies, Canberra.

Mathews, R.H. n.d., MS 8006, National Library of Australia, Canberra.

Officer, C. n.d., MS XM 1514, Museum Victoria, Melbourne.

Officer, S. n.d., MS 9891, State Library of Victoria, Melbourne.

Pastoral Run Plans n.d., VPRS15899, VPRS 5920, VPRS 44, Public Record Office of Victoria, Melbourne.

Ryan, E. 2002, 'Blown to Witewitekalk', in The Land is a Map: Placenames of Indigenous Origin in Australia, L. Hercus, F. Hodges and J. Simpson (eds), Pandanus Books in association with Pacific Linguistics, Canberra: 157-164.

Smyth, R.B. 1878, The Aborigines of Victoria: with notes relating to the habits of the natives of other parts of Australia and Tasmania, 2 Volumes, Victorian Government Printer, Melbourne.

Tindale, N., n.d. MS AA338 131/2, South Australian Museum, Adelaide. 
This text taken from Indigenous and Minority Placenames: Australian and International Perspectives, Edited by Ian D. Clark, Luise Hercus and Laura Kostanski, published 2014 by ANU Press, The Australian National University, Canberra, Australia. 